\title{
Октябрьское рудное поле (Четласский Камень, Средний Тиман): Ar-Ar данные
}

Удоратина О.В. ${ }^{1}$, Травин А.В. ${ }^{2,3,4}$, Бурцев И.Н. ${ }^{1}$, Куликова К.В. ${ }^{1}$, Губарев И.А. ${ }^{5}$

${ }^{1}$ Институт геологии ФИЦ КомиНЦУрО РАН, Сыктывкар, udoratina@geo.komisc.ru

${ }^{2}$ ИГМ СО РАН, Новосибирск, travin@igm.nsc.ru

${ }^{3}$ НГУ, Новосибирск

${ }^{4}$ ТГУ, Томск

${ }^{5}$ КФУ институт геологии и нефтегазовых технологий, Казань, i.gubarev2014@yandex.ru

Аннотация. В статье приводятся данные о возрасте щелочных рудных (Nb, Y-HREE) метасоматитов, полученные ${ }^{40} \mathrm{Ar} /{ }^{39} \mathrm{Ar}$ методом. Калиевый полевой шпат один из ведущих минералов метасоматитов. Калиевый полевой шпат по рентгеноструктурным данным является максимальным микроклином, температура кристаллизации оценивается на уровне $420^{\circ} \mathrm{C}$. В химическом составе микроклина содержание $\mathrm{Na}_{2} \mathrm{O}$ незначительно - 0.16-1 мас. \%. Возраст $\left({ }^{40} \mathrm{Ar} /{ }^{39} \mathrm{Ar}\right)$ составил $513.2 \pm 3.8$ млн. лет.

Ключевые слова: щелочной метасоматоз; рудные редкометалльно-редкоземельные метасоматиты, ${ }^{40} \mathrm{Ar} /{ }^{39} \mathrm{Ar}$ возраст, Средний Тиман.

\section{October Ore Field (Chetlas Stone, Middle Timan): Ar-Ar data}

\author{
Udoratina O.V. ${ }^{1}$, Travin A.V. ${ }^{2,3,4}$, Burtsev I.N. ${ }^{1}$, Kulikova K.V. ${ }^{1}$, Gubarev I.A. ${ }^{4}$ \\ ${ }^{1}$ Institute of Geology, FRC, KomiSC, Ural Branch, Russian Academy of Sciences, Syktyvkar, \\ udoratina@geo.komisc.ru \\ ${ }^{2}$ IGM SB RAS, Novosibirsk,travin@igm.nsc.ru \\ ${ }^{3}$ NSU, Novosibirsk \\ ${ }^{4}$ TSU, Tomsk \\ ${ }^{5}$ KFU Institute of Geology and Oil and Gas Technologies, Kazan, i.gubarev2014@yandex.ru
}

\begin{abstract}
The article presents data on the age of alkaline ore (Nb, Y-HREE) metasomatites obtained by the ${ }^{40} \mathrm{Ar} /{ }^{39} \mathrm{Ar}$ method. The bulk of metasomatites is composed of potassium feldspar. According to X-ray diffraction data, potassium feldspar is the maximum microcline; the crystallization temperature is estimated at $420{ }^{\circ} \mathrm{C}$. In the chemical composition of microcline, the $\mathrm{Na} 2 \mathrm{O}$ content is insignificant - $0.16-1 \mathrm{wt} . \%$. The age $\left({ }^{40} \mathrm{Ar} /{ }^{39} \mathrm{Ar}\right)$ was $513.2 \pm 3.8 \mathrm{Ma}$.

Keyword: alkaline metasomatism; ore rare-metal-rare-earth metasomatites, ${ }^{40} \mathrm{Ar} /{ }^{39} \mathrm{Ar}$ age, Middle Timan.
\end{abstract}

\section{Введение}

На Среднем Тимане известна группа комплексных редкометалльно-редкоземельных проявлений образующих Косьюскую группу (Ивенсен, 1964, Костюхин, Степаненко, 1987). Октябрьское рудное поле входит в ее состав, рудные породы выведены на поверхность в верховье р. Светлая на Четласском Камне. Ведущими рудными минералами являются колумбит и ксенотим.

Рудное поле слагают метапесчаники светлинской свиты четласской серии $\left(\mathrm{RF}_{2} \mathrm{sv}\right)$. Породы претерпели в различной степени метасоматические изменения вплоть до фенитов, микроклинитов, а также рудных альбититов, содержащих редкометалльно-редкоземельную минерализацию.

Возраст метапесчаников светлинской свиты оценивается как позднерифейский - U-Pb датировки (LA ICP MS) по циркону из кварцитопесчаников Новобобровского рудного поля, возраст самого молодого циркона составляет 1100 млн лет (Удоратина и др., 2017), близкий возраст получен на стратотипах (Брусницына и др., 2019).

Возраст (K-Ar метод) для магматитов и метасоматитов, прорывающих породы четласской серии, имеет разброс значений в широком диапазоне от 460 до 1030 млн. лет (Тиманский кряж, 2009).

Редкометалльно-редкоземельное оруденение, локализованное в натриевых и калиевых метасоматитах, генетически связывается с ультраосновными и карбонатитовыми породами Косью, возраст которых оценивается K-Ar (вал) и ${ }^{40} \mathrm{Ar} /{ }^{39} \mathrm{Ar}$ (по флогопиту) методами на уровне 600 млн лет 
(Андреичев, Степаненко, 1983, Удоратина, Травин, 2014, Степаненко, 2015). Есть точка зрения, что возраст магматических образований древнее и составляет $820 \pm 9$ млн. лет (Rb-Sr метод по валу (Макеев и др., 2009)).

Возраст, определенный по рудным минералам Новобобровского проявления, которое расположено в непосредственной близости от Октябрьского рудного поля, составляет соответственно $552 \pm 31$ (U-Th-Pb по монациту) и $581 \pm 47$ млн. лет ( $\mathrm{Sm}-\mathrm{Nd}$ по торит-колумбит-монациту) (Удоратина и др., 2015, 2016, Удоратина, Капитанова, 2017).

Некоторые исследователи считают процессы щелочного метасоматоза и рудогенеза более древними на основании датирования альбита из цемента брекчированного ксенолита (Косьюское рудное поле), его возраст $\left({ }^{40} \mathrm{Ar} /{ }^{39} \mathrm{Ar}\right.$ метод) составляет $845 \pm 8$ млн. лет (Голубева и др., 2019).

Объектом настоящих исследований являются калиевые метасоматиты Октябрьского рудного поля - состав и возраст. Геохронология рудных пород и связанных с ними щелочных метасоматитов мало изучена, так как рудные образования сложные, многостадийные, но при этом близ одновременные и кратковременные в масштабах геологического времени образования.

\section{Методика исследований}

При проведении тематических исследований (ИГ Коми НЦ УрО РАН, 2016 г.) рудных редкометалльно-редкоземельных образований Среднего Тимана, произведено опробование пород рудного поля для исследования изотопно-геохронологическими методами. Для датирования отобран калиевый полевой шпат, в ЦКП «Геонаука» (г. Сыктывкар) исследовался его рентгеноструктурный и химический состав. Структурный контроль минеральной принадлежности проводился рентгеновским дифракционным анализом (дифрактометр Shimadzu XRD-6000 Cu-анод, ток - 30 $\mathrm{mA}$, напряжение - $30 \mathrm{kV}$, фильтр $\mathrm{Ni}$, углы сканирования $2 \theta$ от 2 до 60 градусов, шаг сканирования $2 \theta-0.05$, скорость съемки - 1 гр./мин. Параметры элементарной ячейки минералов рассчитывались с помощью программы Unit Cell. Микрозондовые исследования проведены на спектральном элек-

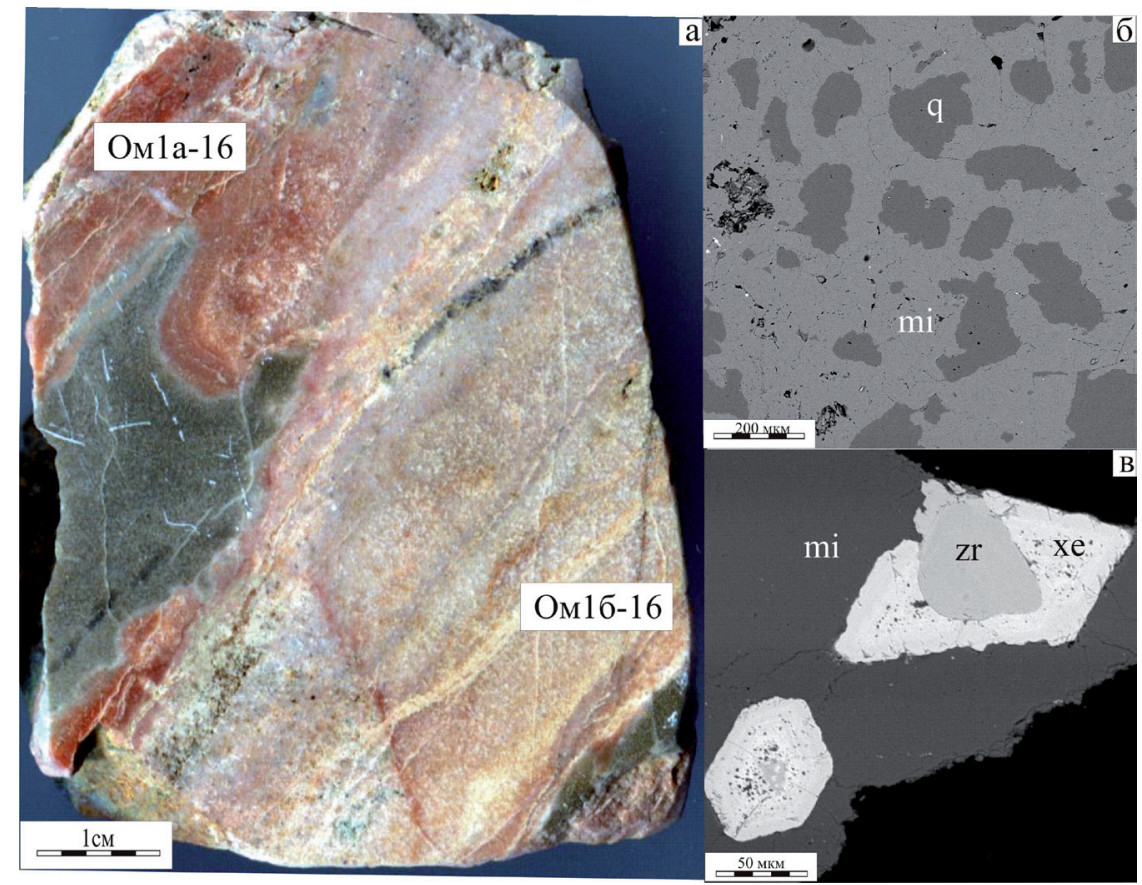

Рис. 1 Щелочной (Ab-Mi) метасоматит по кварцитопесчанику, обр. OM1-16 (a), изображение в обратно рассеянных электронах: $\sigma$ - исследованный микроклин, в - ксенотим с детритовым цирконом в микроклине. $\mathrm{Ab}$ - альбит, q - кварц, mi - микроклин, zr - циркон, хе - ксенотим.

Fig. 1. Alkaline (Ab-Mi) quartzitic sand metasomatite, sample OM1-16 (a), image in backscattered electrons: $\mathrm{b}$ - studied microcline, $\mathrm{c}$ - xenotime with detrital zircon in microcline. Ab - albite, $\mathrm{q}$ - quartz, mi - microcline, $\mathrm{zr}-$ zircon, xe-xenotime. 


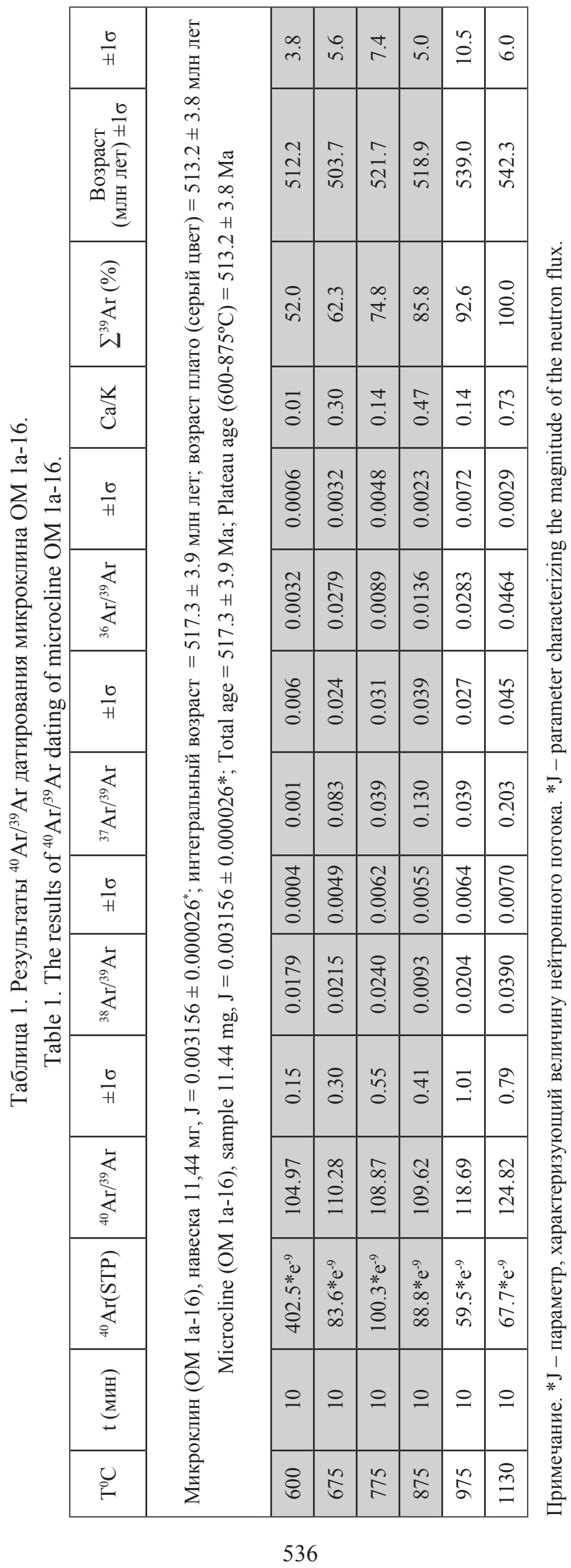




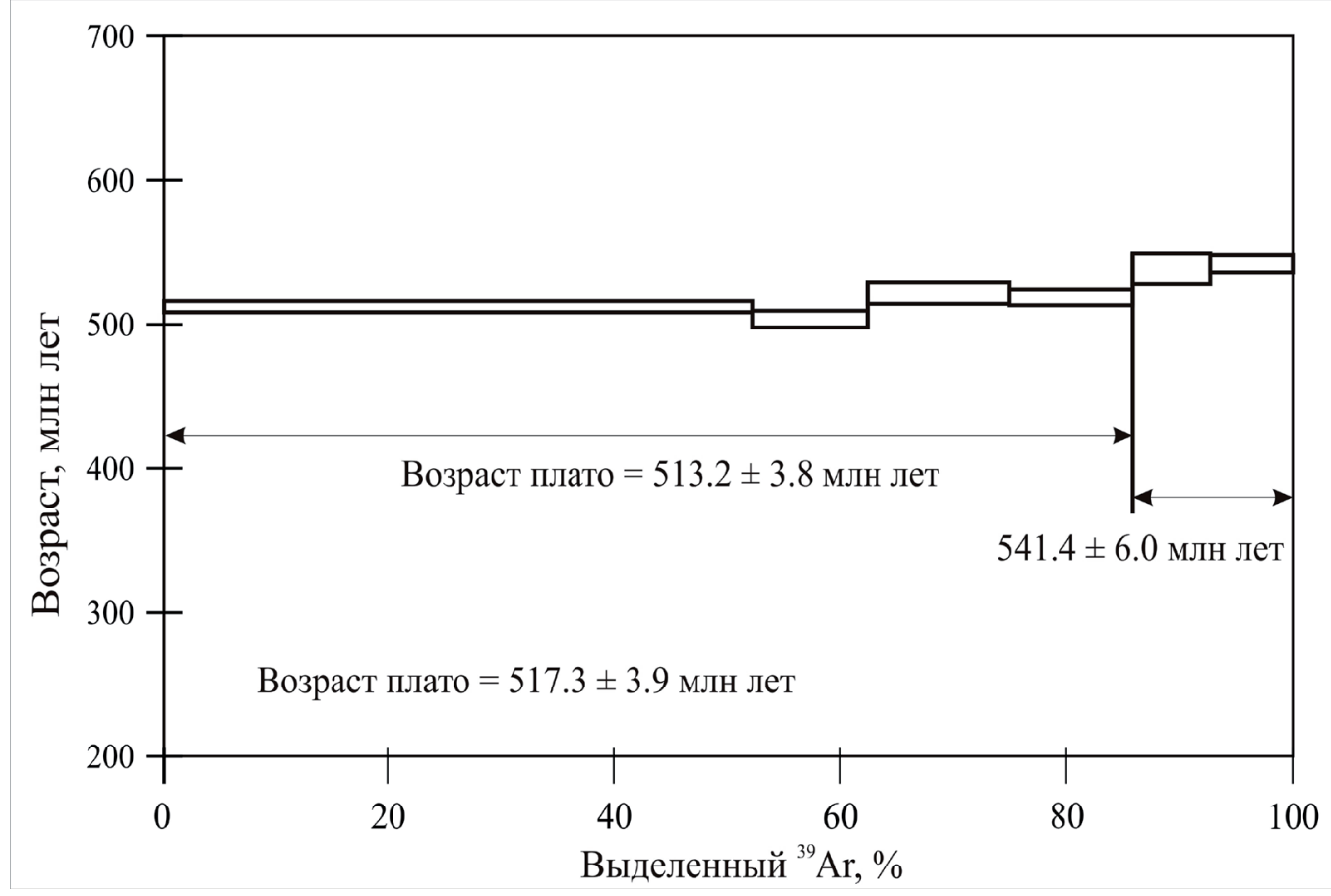

Рис. 2. Результаты ${ }^{40} \mathrm{Ar} /{ }^{39} \mathrm{Ar}$ датирования методом ступенчатого прогрева для максимального микроклина OM1а-16: возрастной спектр.

Fig. 2. Results of ${ }^{40} \mathrm{Ar} /{ }^{39} \mathrm{Ar}$ dating using the stepwise heating method for the maximum microcline OM1a-16: age spectrum.

тронном микроскопе Tescan Vega 3 LMH с энергодисперсионным детектором X-MAX 50mm Oxford Instruments. В ИГМ СО РАН г. Новосибирск выполнено ${ }^{40} \mathrm{Ar} /{ }^{39} \mathrm{Ar}$ датирование методом ступенчатого нагрева (Травин и др., 2009) монофракции калиевого полевого шпата.

\section{Результаты исследований}

Для исследований отобрана монофракция калиевого полевого шпата (проба ОМ1а-16) из метасоматизированного (альбитизированного, калишпатизированного и эгиринизированного) кварцитопесчаника. Калиевый полевой шпат ярко розового цвета образует плотный, сливной тонкозернистый агрегат (рис. 1 a).

Петрографические исследования в калиевом метасоматите по кварцитопесчанику показывают, что процесс метасоматоза происходил за счет растворения кварцитовой матрицы и замещения калиевым полевым шпатом всех минералов.

Исследования калиевого полевого шпата методом порошковой дифрактометрии, для определения степени однородности калишпатовой фазы, степени триклинности, упорядоченности показали следующее: для изученной монофракций КПШ положение отражения (20) и величина $\mathrm{d}=4.23$ свидетельствуют о незначительной примеси альбитового компонента в его составе. Данный полевой шпат является триклинным, так как его степень триклинности $(\Delta \mathrm{p})$ равна 0.875 , что следует из разобщенности пиков (131) и (11) (Рентгенография.., 1983). Используя методики Д. Стюарта и Т. Райта, а также И.Е. Каменцева и О.Г. Сметанниковой, описанные в (Рентгенография.., 1983), по положению дифракционных максимумов (060) и () соответственно определили Al-Si упорядоченность $(2 \mathrm{t} 1=0.96)$, что соответствует максимальному микроклину. Кристаллизация полевых шпатов происходит в достаточно широком интервале температуры и давления, которые влияют на их структурные особенности (Рентгенография.., 1983). Для исследованного микроклина температура соответствует $420^{\circ} \mathrm{C}$.

По данным микрозондового анализа содержание оксида натрия в калиевом полевом шпате в основном незначительно и варьирует от 0.16 до 0.29 мас. \%, что соответствует содержанию альби- 
тового минала не более $2.5 \%$, только в одном из зерен альбитовый минал достигает $10 \%$. Обнаружено, что микроклин содержит реликтовый наследованный кварц (рис. 1, б), также порода насыщена акцессорным ксенотимом (рис. 1, в), наличие в ядерных частях ксенотимов наследованного окатанного (детритного) циркона, наряду с кварцем подтверждает, что формирование щелочных метасоматитов происходило по кварцитопесчаникам.

Результаты датирования показаны на рис. 2. В возрастном спектре выделяется надежное плато, характеризующееся 80 \% выделенного ${ }^{39} \mathrm{Ar}$ и возрастом $513.2 \pm 3.8$ млн. лет.

Полученный возраст плато, по всей видимости, соответствует закрытию изотопной системы полевого шпата (порядка $220-240^{\circ} \mathrm{C}$ ). Можно предположить, что на Октябрьском рудном поле проявилось несколько импульсов преобразований различной интенсивности. Возраст плато соответствует последнему событию, в то время, как оценкой возраста раннего этапа может служить значение, рассчитанное для высокотемпературного плато из двух ступеней - $541 \pm 6$ млн. лет.

Таким образом, метасоматический процесс преобразования кварцитопесчаников Октябрьского рудного поля протекал, мог протекать в несколько кратковременных стадий с возрастом $541 \pm 6$, а также $-513 \pm 4$ млн. лет. На данный момент эти значения - самые молодые среди полученных по рудным образованиям Косьюской группы редкометалльно-редкоземельных проявлений.

Работа выполнена в рамках госзаданий № ГР АААА-А17-117121270035-0,

AAAA-A17-117122790037-0.

\section{Литература}

1. Андреичев В.Л., Степаненко В.И. Возраст карбонатитового комплекса Среднего Тимана // Рудообразование и магматизм севера Урала и Тимана. Сыктывкар. Тр. Ин-та геологии Коми филиала АН СССР. 1983. Вып. 41. С. 83-87.

2. Брусницына Е.А., Ершова В.Б., Худолей А.К., Андерсен Т. Результаты исследований U-Pb изотопного возраста обломочных цирконов из средне-верхнерифейских отложений Четласского Камня (Средний Тиман) // Структура, вещество, история литосферы Тимано-Свероуральского сегмента: Матер. 28-й науч. конф. Сыктывкар: ИГ Коми НЦ УрО РАН. 2019. С. 7-11.

3. Голубева И.И., Бурцев И.Н., Травин А.В., Ремизов Д.Н., Филиппов В.Н., Шуйский А.С. Парагенетическая связь флюидизатно-эксплозивных ультрамафитов дакового комплекса с карбонатитами (Средний Тимман) // Геология и минеральные ресурсы Европейского северо-востока России. Мат-лы XVII Геологического съезда Республики Коми. Сыктывкар. 2019. С. 22 - 24.

4. Ивенсен Ю.П. Магматизм Тимана и полуострова Канин. М.-Л. Изд-во: Наука. 1964. 126 с.

5. Макеев А.Б., Андреичев В.Л., Брянчанинова Н.И. Возраст лампрофиров Среднего Тимана: первые RbSr данные // Докл. АН. 2009. Т. 426. № 1. С. 94-97.

6. Рентгенография основных типов породообразующих минералов (слоистые и каркасные силикаты) / Под ред. В.А. Франк-Каменецкого. Л. Изд-во: Недра.1983. 359 с.

7. Степаненко В.И. Позднепротерозойский магматизм северо-восточной окраины Восточно-Европейской платформы // Тектоника и геодинамика континентальной и океанической литосферы: общие и региональные аспекты. Мат-лы XLVII Тектонического совещ. Т. ІІ. М. Изд-во: ГЕОС. 2015. С. 188-191. ISBN 978-5-89118-693-4.

8. Тиманский кряж. Т. 2. Литология и стратиграфия,геофизическая характеристика земной коры, тектоника, минерально-сырьевые ресурсы (Ред. Л.П. Шилов, А.М. Плякин, В.И. Алексеев). Ухта. Изд-во: УГТУ. 2009. $460 \mathrm{c.}$

9. Травин А.В., Юдин Д.С., Владимиров А.Г., Хромых С.В., Волкова Н.И., Мехоношин А.С., Колотилина Т.Б. Термохронология Чернорудской гранулитовой зоны (Ольхонский регион. Западное Прибайкалье). Геохимия. 2009. № 11. С. 1181-1199.

10. У Уоратина О.В., Вирюс А.А., Козырева И.В, Швецова И.В., Капитанова В.А. Возраст монацитов жильной серии четласского комплекса (Средний Тиман): Th-U-Pb данные // Вестник Института геологии Коми НЦ УрО РАН. Сыктывкар. 2015. № 3. С. 23-29.

11. Удоратина О.В., Казанцева М.И., Саватенков В.M. Sm-Nd датирование рудных минералов Новобобровского месторождения (Средний Тиман) // Щелочной магматизм Земли и связанные с ним месторождения стратегических металлов. Тр. ХХХІІІ межд. конф. Москва. ГЕОХИ. 27 мая 2016 г. (отв. ред. акад. Когарко Л.Н.). М. Изд-во: ГЕОХИ РАН. 2016. С. 134-136.

12. Удоратина О.В., Травин А.В. Щелочные пикриты четласского комплекса Среднего Тимана: $\mathrm{Ar}-\mathrm{Ar}$ данные // Рудный потенциал щелочного, кимберлитового и карбонатитового магматизма. Матер. 30 Международной конференции. Анталия-Москва. 2014. С. 82-84. 